\title{
Mineral Processing of Eudialyte Ore from Norra Kärr
}

\author{
${\text { Theresa } \operatorname{Stark}^{1} \cdot \text { Ivan Silin }^{1} \cdot \text { Hermann Wotruba }}^{1}$
}

(C) The Minerals, Metals \& Materials Society (TMS) 2016

\begin{abstract}
Eudialytes are a nonconventional source for rare earth elements (REE). As the total REE content of eudialytes is relatively low, high-grade mineral concentrates have to be produced. The applicability of magnetic separation and direct selective flotation for the processing of eudialyte ore from Norra Kärr (Sweden) was tested. The eudialyte in the used sample contains around $4 \%$ of REE. Magnetic separation is applicable for eudialyte ore processing. The higher the strength of the magnetic field, the higher the recovery. Recovery of around $81 \%$ of REE was achieved in a two-stage process of rougher and scavenger at a mass reduction of $48 \%$. The concentrate grade of around $0.76 \%$ REE is not sufficient for further hydrometallurgical processing steps. A newly developed reagent regime for the direct selective flotation of eudialyte from eudialyte ore was tested with different samples. The regime consists of oxalic acid and sodium hexametaphosphate as depressants and a mixture of mono/di phosphoric acid esters as collector, at a $\mathrm{pH}$ below 4 . This new method proved applicable for raw ore as well as magnetic preconcentrate. Concentrates with grades of around $2 \% \Sigma \mathrm{Y}$, $\mathrm{Ce}$, La were produced.
\end{abstract}

Keywords Nepheline-syenite · Norra Kärr · Eudialyte · Magnetic separation · Flotation

The contributing editor for this article was Bernd Friedrich.

Ivan Silin

silin@amr.rwth-aachen.de

1 Unit of Mineral Processing, RWTH Aachen University, Lochnerstraße 4-20, Haus C, 52064 Aachen, Germany

\section{Introduction}

Today rare earth elements are mainly produced from bastnaesite, loparite, monazite, xenotime, and ion-adsorption clays [1]. With the exception of the ion-adsorption clays, these deposits often contain elevated levels of thorium and uranium [2]. To minimize environmental and safety risks, it is important to research alternative sources for rare earths, containing lower levels of radioactive elements.

One such source could be the mineral group of $\mathrm{Na}, \mathrm{Ca}$, $\mathrm{Zr}$-, and REE-bearing silicates-eudialytes with the International Mineralogical Association (IMA) accepted formula as [3]:

$$
\mathrm{N}_{15}[\mathrm{M}(1)]_{6}[\mathrm{M}(2)]_{3}[\mathrm{M}(3)][\mathrm{M}(4)] \mathrm{Z}_{3}\left[\mathrm{Si}_{24} \mathrm{O}_{72}\right] \mathrm{O}_{4}^{\prime} \mathrm{X}_{2}
$$

$\mathrm{N}=\mathrm{Na}, \mathrm{Ca}, \mathrm{K}, \mathrm{Sr}, \mathrm{REE}, \mathrm{Ba}, \mathrm{Mn}, \mathrm{H}_{3} \mathrm{O}^{+}$;

$\mathrm{M}(1)=\mathrm{Ca}, \mathrm{Mn}, \mathrm{REE}, \mathrm{Na}, \mathrm{Sr}, \mathrm{Fe}$;

$\mathrm{M}(2)=\mathrm{Fe}, \mathrm{Mn}, \mathrm{Na}, \mathrm{Zr}, \mathrm{Ta}, \mathrm{Ti}, \mathrm{K}, \mathrm{Ba}, \mathrm{H}_{3} \mathrm{O}^{+}$;

$\mathrm{M}(3,4)=\mathrm{Si}, \mathrm{Nb}, \mathrm{Ti}, \mathrm{W}, \mathrm{Na}$;

$\mathrm{Z}=\mathrm{Zr}, \mathrm{Ti}, \mathrm{Nb}$;

$\mathrm{O}^{\prime}=\mathrm{O}, \mathrm{OH}^{-}, \mathrm{H}_{2} \mathrm{O}$

$\mathrm{X}=\mathrm{H}_{2} \mathrm{O}, \mathrm{Cl}^{-}, \mathrm{F}^{-}, \mathrm{OH}^{-}, \mathrm{CO}_{3}^{2-}, \mathrm{SO}_{4}^{2-}, \mathrm{SiO}_{4}^{4-}$.

Unlike other rare earth minerals, rare earth bearing eudialytes are usually not enriched in thorium and uranium. Many eudialytes have a relatively low content of REE compared to bastnaesite or monazite. Therefore high-grade eudialyte concentrates are required in order to ensure economical metallurgical processing. But eudialytes often have a relatively high ratio of valuable heavy rare earth elements (HREE) to light rare earth elements (LREE).

Eudialytes occur all over the world [4]. Examples of rare earth-enriched eudialyte ores are Lovozero (Russia), 
Ill'maussaq (Greenland), Nechalacho (Canada) with an average of $1.71 \%$ TREO (total rare earth oxides), of which $22.5 \%$ are HREO (heavy rare earth oxides) [5] and Norra Kärr (Sweden) with an average grade of $0.59 \%$ TREO, of which over $50 \%$ are HREO [6].

\section{Magnetic Separation}

\section{Sample Material}

For the test work, eudialyte ore from Norra Kärr, Sweden was used. The Norra Kärr eudialyte ore is a nephelinesyenite intrusion [7]. The main components are nepheline, feldspars, aegirine, and eudialyte. These make up more than $90 \%$ of the samples. Nepheline and feldspars have a similar mineralogy and behave similarly in the tested processes, so they are regarded as one group in the tests.

The mineral composition and content of $\mathrm{Zr}$ and $\Sigma \mathrm{Y}, \mathrm{Ce}$, La of the ore is shown in Table 1.

For the wet magnetic separation tests, two samples were comminuted into different particle sizes. One sample was comminuted into a top size of $100 \mu \mathrm{m}$, the other one into a top size of $250 \mu \mathrm{m}$. These samples were not deslimed.

\section{Initial Dry Magnetic Separation Tests}

Dry tests were carried out on a High-Intensity Induced-Roll Magnetic Separator (IRS) to test the influence of different magnetic field strengths. The machine used was a model MIH(13)111-5, by Carpco Inc. For these initial tests, an induced-roll magnetic separator was used, because it enables tests with lower amounts of sample material compared to a JONES magnetic separator, and the dry products are easier and quicker to handle and analyze.

The maximal magnetic field strength that can be achieved with the IRS is $1 \mathrm{~T}$. The initial test series with the IRS unveiled that the stronger the magnetic field the higher the recovery of $\Sigma \mathrm{Y}, \mathrm{Ce}, \mathrm{La}$ into the magnetic concentrate. After this proof of concept, it was decided on to use a JONES-type separator for further tests.

\section{Wet Magnetic Separation Tests}

Based on the results of the initial tests, a Wet High-Intensity Magnetic Separator (WHIMS) of the JONES-type, model JONES P40, by Humboldt Wedag AG (now MBE Coal \& Minerals Technology GMBH) was chosen for the tests, for its high-intensity magnetic field of up to $1.5 \mathrm{~T}$. Two test were carried out, using samples of different particle sizes. One sample had particle sizes of $0-250 \mu \mathrm{m}$, the other had particle sizes of $0-100 \mu \mathrm{m}$. Each test consisted of two separation stages. In the first stage, three products were produced. The second stage varied for the different samples. For the sample of $0-250 \mu \mathrm{m}$, the nonmagnetic fraction was refed as a scavenger step (Fig. 1). For the sample of $0-100 \mu \mathrm{m}$, the middlings were re-fed onto the JONES magnetic separator as a cleaner step (Fig. 2). All tests on the JONES magnetic separator were conducted using the maximum achievable field strength of about 1.4-1.5 T at distances between the plates of $1.4 \mathrm{~mm}$ for the sample $<250 \mu \mathrm{m}$ and $0.8 \mathrm{~mm}$ for the sample $<100 \mu \mathrm{m}$. The slurry density of the feed was $35 \%$.

\section{Results and Discussion}

The mean magnetic susceptibility of aegirine is higher than that of eudialyte, but the ranges overlap. Nepheline and feldspars have lower magnetic susceptibilities than eudialyte. Therefore, it is not possible to produce a clean eudialyte concentrate in one stage of magnetic separation. Also the content of nepheline/feldspars in the ore is higher than that of aegirine. Nepheline/feldspars are easier to separate using magnetic separation and more mass can be rejected.

The tests show that the results achieved in the scale up with the JONES magnetic separator were not as good as the initial tests. The finer sample yielded better results, probably due to the better liberation of the minerals. The particle size of 0-250 $\mu \mathrm{m}$ was used to test whether magnetic preconcentration before flotation is possible at larger particle sizes. This would decrease the amount of material that has to be milled to flotation size. The results of the tests are shown in Table 2.

Table 1 Mineral composition and content of $\mathrm{Zr}$ and $\Sigma \mathrm{Y}, \mathrm{Ce}$, La of the sample used for magnetic separation

\begin{tabular}{|c|c|c|c|c|c|}
\hline \multicolumn{4}{|l|}{ Mineral assay } & \multicolumn{2}{|c|}{ Elemental assay } \\
\hline Eudialyte grade $(\%)$ & Catapleiite grade $(\%)$ & Aegirine grade $(\%)$ & Nepheline + Feldspars grade $(\%)$ & $\begin{array}{l}\mathrm{Zr} \text { grade } \\
(\%)\end{array}$ & $\Sigma \mathrm{Y}, \mathrm{Ce}, \mathrm{La}$ grade $(\%)$ \\
\hline 12.6 & 1.9 & 15.2 & 69.1 & 1.35 & 0.32 \\
\hline
\end{tabular}

For the initial dry magnetic separation tests, a sample was ground to $<160 \mu \mathrm{m}$ and deslimed at $40 \mu \mathrm{m}$ 


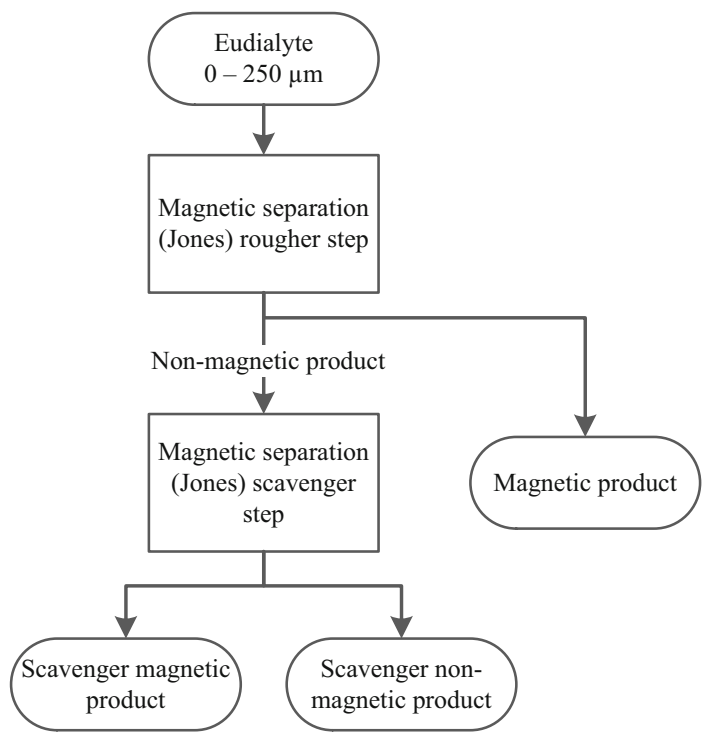

Fig. 1 Scheme of two-stage magnetic separation test with sample size $0-250 \mu \mathrm{m}$

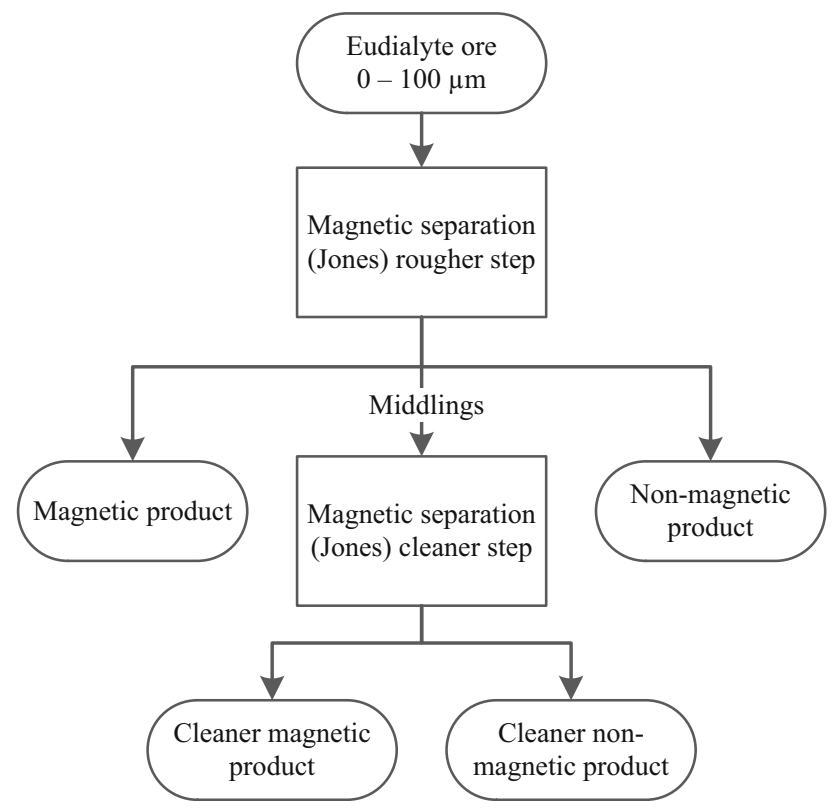

Fig. 2 Scheme of two-stage magnetic separation test with sample size $0-100 \mu \mathrm{m}$

For the coarser sample $<250 \mu \mathrm{m}$, the highest $\Sigma$ Y, Ce, La grade is achieved in the magnetic product of the first separation stage at about $0.492 \%$ at a low recovery of around $64 \%$. With the scavenging of the nonmagnetic fraction, the recovery can be increased to $80.58 \%$ at a mass yield of $52.09 \%$. The grade of the concentrate is reduced to $0.486 \%$.

For the finer sample $<100 \mu \mathrm{m}$, the recoveries are lower, because the process was designed to achieve higher concentrate grades. The recovery of $\Sigma \mathrm{Y}, \mathrm{Ce}, \mathrm{La}$ in the first stage concentrate is $47.16 \%$. In the cleaner stage, the highest grade concentrate of the tests is achieved at $0.78 \%$ $\Sigma \mathrm{Y}, \mathrm{Ce}, \mathrm{La}$, but the recovery into this concentrate is low at $17.69 \%$. The combined concentrates of both stages have a concentrate grade of $0.56 \%$. With the second stage, the recovery only increased to a total of $64.39 \%$, but the mass yield is lower than with the sample $<250 \mu \mathrm{m}$ at $34.73 \%$.

With more stages of scavenging and cleaning, an increase in recovery and mass reduction is expected. The concentrate grades achieved by magnetic separation are not sufficient. The mass reduction in this relatively easy process shows its applicability as a preconcentration step before flotation.

\section{Flotation}

\section{Literature Review}

The flotative separation of eudialyte is a complex task, due to several factors. All main minerals of eudialyte ores (eudialyte, nepheline, feldspars, and aegirine) are silicates and consist of the same cations $\mathrm{K}^{+}, \mathrm{Na}^{+}, \mathrm{Ca}^{2+}, \mathrm{Mg}^{2+}$, $\mathrm{Fe}^{3+/ 2+}, \mathrm{Al}^{3+}$, and $\mathrm{Si}^{4+}$. Like all nonsulfidic ores, eudialyte ores are sensitive to multivalent metallic cations such as $\mathrm{Ca}^{2+}, \mathrm{Mg}^{2+}, \mathrm{Fe}^{3+}$ and have to exchange ions. In addition, nepheline and eudialyte are easily soluble in inorganic acids and bases [8].

The floatability of the following minerals increases in ascending order: nepheline $\rightarrow$ feldspars $\rightarrow$ eudialyte $\rightarrow$ aegirine [9]. The isoelectric points lie between 3.5 and 4.5 for eudialyte [8], 2.4 and 4 for nepheline [10], 3.8 for aegirine and 1.4-1.6 for feldspars [11]. As collectors for eudialyte and main minerals of eudialyte ores, sodium oleate, distilled fatty acid, hydroxamic acid, dodecylamine, alkyl phosphate [12], and isooctyl phosphate [10] have been tested. As depressants, sodium carbonate, sodium sulfide, hydrofluoric acid [12], potassium manganite (VII), and hydrogen peroxide [8] have been tested.

Currently, only a two-step selective flotation process for eudialyte ore from the Lovozero-Massif (Kola-peninsula, Russia) is known. In this process, the most flotative mineral aegirine is floated in the first step, using distilled fatty acid $(300 \mathrm{~g} / \mathrm{t})$ at a $\mathrm{pH}$ of $8-9.5$. Eudialyte, nepheline, and feldspars are depressed using sodium carbonate $(700 \mathrm{~g} / \mathrm{t})$. The tailings of aegirine flotation are washed and floated a second time. In this step, nepheline and feldspars are depressed using sodium hydroxide $(2 \mathrm{~kg} / \mathrm{t}$ or more). Eudialyte is floated using sodium oleate $(700 \mathrm{~g} / \mathrm{t})$ or SIN TAF-Collector (alkyl phosphate C10-C18, 800-1000 g/t) at a $\mathrm{pH}$ of $6.5-7[8,9,13]$. 
Table 2 Yield and grade of $\Sigma$ $\mathrm{Y}, \mathrm{Ce}, \mathrm{La}$ of two-stage magnetic separation products

\begin{tabular}{llclc}
\hline Sample & Product & Yield $(\%)$ & \multicolumn{2}{l}{$\Sigma$ Y, Ce, La } \\
\cline { 4 - 5 } & & & Grade (\%) & Recovery (\%) \\
\hline Feed & & 100 & 0.32 & 100 \\
$<250 \mu \mathrm{m}$ & Magnetic & 41.34 & 0.49 & 64.21 \\
& Scavenger magnetic & 10.75 & 0.46 & 16.37 \\
& Scavenger nonmagnetic & 47.91 & 0.12 & 19.42 \\
$<100 \mu \mathrm{m}$ & Magnetic & 27.69 & 0.51 & 47.16 \\
& Nonmagnetic & 53.05 & 0.18 & 27.01 \\
& Cleaner magnetic & 7.04 & 0.78 & 17.69 \\
& Cleaner nonmagnetic & 12.22 & 0.18 & 7.39 \\
\hline
\end{tabular}

Alternatively, eudialyte can be separated from nepheline and feldspars using magnetic separation, after the aegirine has been floated off [8]. Such a process was proposed for eudialyte ore from Greenland, with modified fatty acid used as collector for aegirine and albite flotation, while eudialyte and nepheline are depressed using sodium sulfide and sodium fluoride 14].

Another alternative is the further reverse flotation of eudialyte. After aegirine flotation, nepheline, sodalite, and quartz were floated at a $\mathrm{pH}$ of $2-4$ using collectors based on amines [15].

To avoid the two-step flotation process, a reagent regime was suggested with which eudialyte could be floated selectively in one step. Recommended depressants for gangue minerals like pyroxene, which contain iron, alkaline metals, and earth alkaline metals, are compounds on the basis of salts of phosphoric and polyphosphorus acids as sodium hexametaphosphate (SHMP) or tetrasodium pyrophosphate (TSPP). Using oxalic acid (50 g/t) and sodium hexametaphosphate $(100 \mathrm{~g} / \mathrm{t})$, loparite $\left((\mathrm{Na}, \mathrm{Ce}, \mathrm{Sr})(\mathrm{Ce}, \mathrm{Th})(\mathrm{Ti}, \mathrm{Nb})_{2} \mathrm{O}_{6}\right)$ was separated from aegirine with the addition of hydroxamic acid (C7-C9) at a $\mathrm{pH}$ of 6.2-6.4 [16]. The separation of baddeleyite $\left(\mathrm{ZrO}_{2}\right)$ from forsterite $\left(\mathrm{Mg}_{2}\left[\mathrm{SiO}_{4}\right]\right)$ is possible using SINTAF-Collector (alkyl phosphate $\mathrm{C} 10-\mathrm{C} 18$ ) and sodium hexametaphosphate in an acidic environment at a $\mathrm{pH}$ of 3-5 [8].

The main difference that can enable the selective flotation of eudialyte is its content of $\mathrm{Zr}$ and REE. The choice of a suitable collector should be based on its selectivity towards $\mathrm{Zr}$ and/or REE. For Zr- and REE-bearing minerals, chelating collectors like hydroxamic acid or phosphoric acid ester have been recommended. The selectivity of collectors on the basis of phosphoric acid esters has been proven: molecules of mono alkyl phosphate (C8) and $\mathrm{Zr}$ on the surface of zircon form a bidentate chelate complex through two hydroxyl groups [17]. Flotation is successful for zircon, baddeleyite, eudialyte, catapleiite, and wöhlerite using isooctyl phosphate [10], for zircon using Flotinor SM 15 [18] and for eudialyte and baddeleyite using SINTAF [8] at acidic $\mathrm{pH}$ levels. In addition, such a collector is scarcely selective toward the gangue minerals (feldspars, foides, amphiboles, and pyroxenes) at acidic pH levels [10].

The previously mentioned facts and successful tests hold the necessary theoretical information for the selection of a suitable reagent regime for the selective flotation of eudialyte. This theoretical regime was tested in a series of pretests using eudialyte ore samples from Lovozero (Russia) and Norra Kärr (Sweden). The tests have shown that the selective flotation of eudialyte is possible, using the following reagents at a $\mathrm{pH}$ of 4 or lower (sulfuric acid) [19]:

- Sodium hexametaphosphate and oxalic acid as depressants for pyroxenes (aegirine), nepheline feldspars;

- Phosphoric acid esters as collectors (the readily available industrial reagent Flotinor SM 15 by Clariant International Ltd.).

\section{Flotation Reagents}

Flotinor SM 15, a mixture of mono/di phosphoric acid esters, supplied by Clariant International Ltd. was used as the collector for eudialyte and other REE-bearing minerals. The collector was used as a $1 \%$ liquid emulsion in water. The industrial collector is currently used for the flotation of fluorite, heavy metal oxides, and for reverse phosphorite flotation [20]. The tests established a good ability of the collector for frothing and promoting froth stability, so that the addition of a separate frother was not necessary.

Sodium hexametaphosphate (extra pure) and oxalic acid dihydrate (99\%-purity) by Carl Roth $\mathrm{GmbH}$ were used as the depressants of aegirine and other gangue minerals. The depressants were dissolved in water as $2.5 \%$ solution. Sulfuric acid solution (5\%) was used for pH-adjustment in mineral flotation.

\section{Sample Material}

For the flotation tests, the three samples A, B and M were used, as well as the magnetic preconcentrates AMP 
(sample A, magnetic product), BMP (sample B, magnetic product), and MMP (sample M, magnetic product). These magnetic products were produced from samples A, B, and $M$ respectively, using dry magnetic separation at $1 \mathrm{~T}$. The particle size of the samples is $40-160 \mu \mathrm{m}$. The mineral composition of the samples used for flotation and their contents of $\mathrm{Zr}$ and $\Sigma \mathrm{Y}, \mathrm{Ce}, \mathrm{La}$ are displayed in Table 3. Eudialyte is the main Zr- und REE-bearing mineral in the samples. The other $\mathrm{Zr}$ - und REE-bearing minerals were also identified: rosenbuschit, mosandrite, rinkite, zircon, lavenite, wöhlerite, and britholite making up less than $0.5 \%$ of the samples.

\section{Flotation Tests}

Deionized water was used for the flotation tests in this study. The flotation tests were carried out in a laboratory flotation machine (model D12, Denver Equipment Company). For each test, $500 \mathrm{~g}$ of sample material was used in a 2-1 flotation cell. The slurry density was $250 \mathrm{~g} / \mathrm{l}$. The rotational speed of the impeller was $1300 \mathrm{rpm}$ constantly, throughout agitation and flotation. The pulp temperature was maintained at $20{ }^{\circ} \mathrm{C}$.

While conditioning, the depressants were added first. Oxalic acid was added before sodium hexametaphosphate. After the addition of the depressants, the $\mathrm{pH}$ was adjusted to 3.6-4.1 using sulfuric acid, and the slurry was mixed for $5 \mathrm{~min}$. The collector was added second and the slurry was mixed for an additional $3 \mathrm{~min}$. After conditioning, the air supply was opened and flotation started. The flotation took 1-3 min on average.

The concentrates of the rougher flotation were cleaned in an open circuit at $\mathrm{pH} 3.3-3.5$ using sulfuric acid. The cleaner flotation was carried out in a 2-1 flotation cell, without adding further reagent.

\section{Results and Discussion}

By combining sodium hexametaphosphate and oxalic acid as depressants, it is possible to achieve selective flotation of eudialyte and REE-bearing minerals. Oxalic acid and sodium hexametaphosphate at a ratio of 1:2 have proven most effective. The optimal dosages are $0.25-1 \mathrm{~kg} / \mathrm{t}$ for oxalic acid and $0.5-2.5 \mathrm{~kg} / \mathrm{t}$ for sodium hexametaphosphate. Dosages of sodium hexametaphosphate of more than $2.5 \mathrm{~kg} / \mathrm{t}$ per flotation stage lead to increased collector consumptions. Collector usage is relatively low at $350 \mathrm{~g} / \mathrm{t}$.

Reagent consumptions and the total balance of products for each sample obtained in flotation tests are shown in Table 4.

Rougher flotation of samples A, B, and M shows, that it is possible to concentrate eudialyte and other Y-, Ce- and

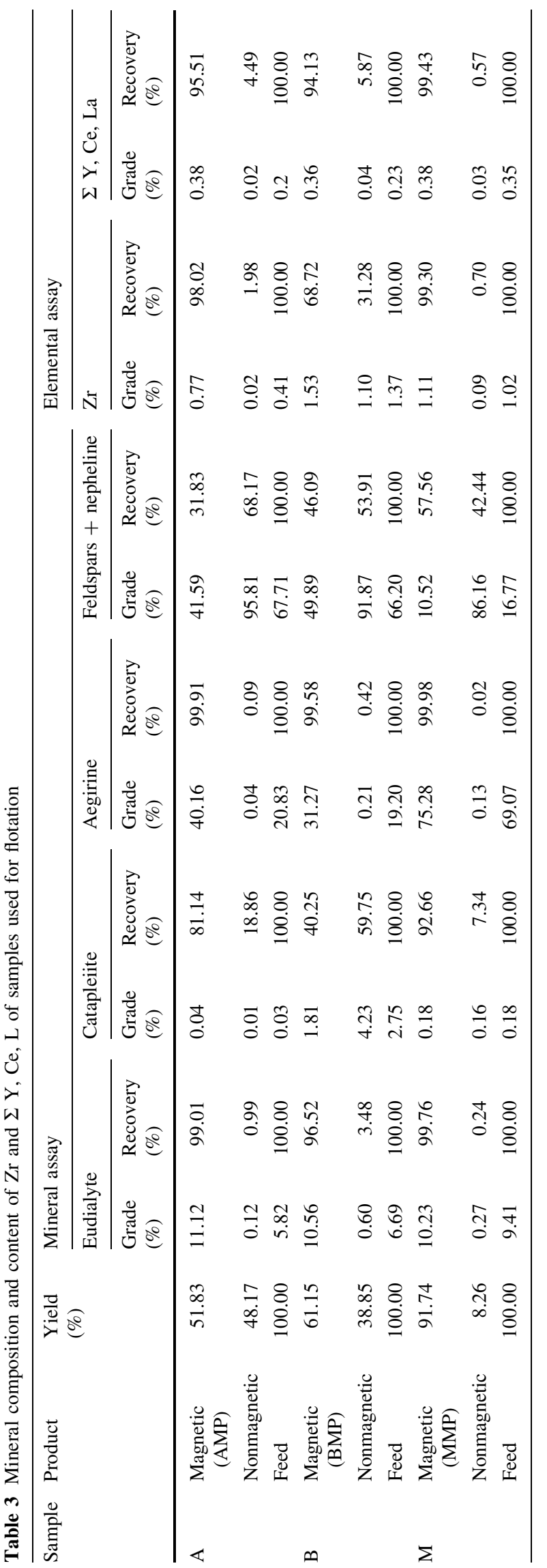


La-bearing minerals into a preconcentrate at recoveries of 80-90\%. Using magnetic separation, the feed entering the flotation process can be reduced by $8-48 \%$. Rougher flotation of the magnetic preconcentrates AMP, BMP, and
MMP shows, that the recoveries stays over $80 \%$. Compared to the rougher flotation of the raw ore samples A, B, and $\mathrm{M}$, the recovery of $\Sigma \mathrm{Y}, \mathrm{Ce}, \mathrm{La}$ is $2-4 \%$ lower, while the grades of $\Sigma \mathrm{Y}, \mathrm{Ce}, \mathrm{La}$ improve and the mass yield into

Table 4 Reagent consumption, yield, and grade of $\mathrm{Zr}$ and $\Sigma \mathrm{Y}, \mathrm{Ce}$, La of all flotation products

\begin{tabular}{|c|c|c|c|c|c|c|c|c|c|}
\hline \multirow[t]{2}{*}{ Sample } & \multicolumn{2}{|l|}{ Depressant } & \multirow{2}{*}{$\begin{array}{l}\text { Collector } \\
\text { Flotinor SM } 15 \\
(\mathrm{~g} / \mathrm{t})\end{array}$} & \multirow[t]{2}{*}{ Products } & \multirow{2}{*}{$\begin{array}{l}\text { Yield } \\
(\%)\end{array}$} & \multicolumn{2}{|l|}{$\mathrm{Zr}$} & \multicolumn{2}{|c|}{$\Sigma \mathrm{Y}, \mathrm{Ce}, \mathrm{La}$} \\
\hline & $\begin{array}{l}\text { Oxalic acid } \\
(\mathrm{g} / \mathrm{t})\end{array}$ & $\begin{array}{l}\text { Sodium } \\
\text { hexametaphosphate }(\mathrm{g} / \mathrm{t})\end{array}$ & & & & $\begin{array}{l}\text { Grade } \\
(\%)\end{array}$ & $\begin{array}{l}\text { Recovery } \\
(\%)\end{array}$ & $\begin{array}{l}\text { Grade } \\
(\%)\end{array}$ & $\begin{array}{l}\text { Recovery } \\
(\%)\end{array}$ \\
\hline \multirow[t]{4}{*}{ A } & 250 & 500 & 350 & $\begin{array}{l}\text { Cleaner } \\
\text { concentrate }\end{array}$ & 9.06 & 2.15 & 55.10 & 2.04 & 75.24 \\
\hline & & & & $\begin{array}{l}\text { Rougher } \\
\text { concentrate }\end{array}$ & 24.72 & 1.14 & 79.77 & 0.90 & 90.47 \\
\hline & & & & Tailings & 75.28 & 0.09 & 20.23 & 0.031 & 9.53 \\
\hline & & & & Feed & 100.0 & 0.35 & 100.00 & 0.25 & 100.00 \\
\hline \multirow[t]{5}{*}{ AMP } & 750 & 1500 & 850 & $\begin{array}{l}\text { Cleaner } \\
\text { concentrate }\end{array}$ & 3.42 & 3.01 & 15.03 & 3.31 & 23.22 \\
\hline & & & & $\begin{array}{l}\text { Rougher } \\
\text { concentrate }\end{array}$ & 13.41 & 2.03 & 75.09 & 1.68 & 86.01 \\
\hline & & & & Tailings & 38.42 & 0.21 & 22.7 & 0.07 & 10.50 \\
\hline & & & & $\begin{array}{l}\text { Tailings } \\
\text { nonMP }\end{array}$ & 48.17 & 0.02 & 2.21 & 0.02 & 3.5 \\
\hline & & & & Feed & 100.0 & 0.36 & 100.00 & 0.26 & 100.00 \\
\hline \multirow[t]{4}{*}{ B } & 1250 & 2500 & 350 & $\begin{array}{l}\text { Cleaner } \\
\text { concentrate }\end{array}$ & 15.85 & 4.19 & 53.02 & 0.71 & 40.91 \\
\hline & & & & $\begin{array}{l}\text { Rougher } \\
\text { concentrate }\end{array}$ & 33.89 & 3.32 & 89.81 & 0.70 & 85.94 \\
\hline & & & & Tailings & 66.11 & 0.193 & 10.19 & 0.059 & 14.06 \\
\hline & & & & Feed & 100.0 & 1.25 & 100.00 & 0.28 & 100.00 \\
\hline \multirow[t]{5}{*}{ BMP } & 1750 & 3500 & 850 & $\begin{array}{l}\text { Cleaner } \\
\text { concentrate }\end{array}$ & 7.93 & 5.94 & 37.31 & 1.56 & 32.89 \\
\hline & & & & $\begin{array}{l}\text { Rougher } \\
\text { concentrate }\end{array}$ & 25.42 & 2.69 & 57.09 & 1.00 & 83.51 \\
\hline & & & & Tailings & 35.73 & 0.25 & 7.30 & 0.09 & 10.79 \\
\hline & & & & $\begin{array}{l}\text { Tailings } \\
\text { nonMP }\end{array}$ & 38.85 & 1.1 & 35.61 & 0.04 & 5.70 \\
\hline & & & & Feed & 100.0 & 1.2 & 100.00 & 0.30 & 100.00 \\
\hline \multirow[t]{4}{*}{ M } & 1250 & 2500 & 350 & $\begin{array}{l}\text { Cleaner } \\
\text { concentrate }\end{array}$ & 9.13 & 5.67 & 55.74 & 2.08 & 61.06 \\
\hline & & & & $\begin{array}{l}\text { Rougher } \\
\text { concentrate }\end{array}$ & 26.35 & 2.78 & 78.96 & 0.99 & 83.65 \\
\hline & & & & Tailings & 73.65 & 0.265 & 21.04 & 0.069 & 16.95 \\
\hline & & & & Feed & 100.0 & 0.93 & 100.00 & 0.31 & 100.00 \\
\hline \multirow[t]{5}{*}{ MMP } & 1250 & 2500 & 350 & $\begin{array}{l}\text { Cleaner } \\
\text { concentrate }\end{array}$ & 9.77 & 5.92 & 52.71 & 2.20 & 57.98 \\
\hline & & & & $\begin{array}{l}\text { Rougher } \\
\text { concentrate }\end{array}$ & 24.65 & 3.21 & 77.93 & 1.17 & 84.45 \\
\hline & & & & Tailings & 67.09 & 0.32 & 21.36 & 0.08 & 14.96 \\
\hline & & & & $\begin{array}{l}\text { Tailings } \\
\text { nonMP }\end{array}$ & 8.26 & 0.09 & 0.71 & 0.02 & 0.59 \\
\hline & & & & Feed & 100.0 & 1.01 & 100.00 & 0.34 & 100.00 \\
\hline
\end{tabular}


the concentrate decreases. Losses of $\mathrm{Zr}$ into the nonmagnetic fraction (sample BMP) are mainly due to the presence of the nonmagnetic mineral catapleiite.

An optimal cleaning step after the initial rougher flotation has not yet been determined. However, a one-stage cleaning of the concentrate in an open circuit has shown that the REE-bearing minerals are concentrated in the froth product. The double cleaner flotation of rougher concentrate (sample AMP) showed that the grade of $\Sigma \mathrm{Y}, \mathrm{Ce}, \mathrm{La}$, $\mathrm{Nd}$, Pr of $9 \%$ in the cleaner concentrate can be achieved at the mass yield of $0.88 \%$ and recovery of $22 \%$.

\section{Conclusions}

Magnetic separation is applicable for the separation of eudialyte and aegirine from feldspars and nepheline, but the concentrate grades are not sufficient. To achieve sufficient recoveries, multiple separation stages are necessary. Magnetic separation is suitable as a preconcentration step before flotation.

To achieve direct selective flotation of eudialyte, a mixture of mono/diphosphoric acid esters as a collector and oxalic acid and sodium hexametaphosphate as depressants have been proven effective at $\mathrm{pH}$ levels below 4 . To find the optimal parameters and best achievable results, the process has to be tested in a continuous operation.

Direct selective flotation is suitable to produce highgrade eudialyte concentrates, which are necessary for feasible metallurgical processing due to the low REE-contents of eudialyte. It simplifies the processing of eudialyte ore. Therefore, it has the potential to increase the feasibility of eudialyte as an REE source.

The proposed reagent regime could be applicable not only for the separation of eudialyte, but also for other minerals from alkaline rock complexes. For example, $\mathrm{Zr}$ bearing oxides and silicates (zircon, baddeleyite, catapleiite, vlasovite, gittinsit), REE-bearing zirconosilicates and titansilicates (rinkite, mosandrite, rosenbuschite), REEbearing silicates (REE-allanite) or phosphosilicates (britholithe, steenstrupine), and $\mathrm{Ta}-\mathrm{Nb}$-bearing minerals could be floated from syenites or nepheline-syenites.

\section{References}

1. Gambogi J (2016) 2013 minerals yearbook-rare earths (advance release). U.S. Geological Survey, Washington, DC
2. Zhu Z, Pranolo Y, Cheng C (2015) Separation of uranium and thorium from rare earths for rare earth production-a review. J Miner Eng 77:185-196. doi:10.1016/j.mineng.2015.03.012

3. Schilling J, Wu F-Y, McCammon C et al (2011) The compositional variability of eudialyte-group minerals. Mineral. Mag 75(I):87-115. doi:10.1180/minmag.2011.075.1.87

4. The Hudson Institute of Mineralogy (2016) Eudialyte. http:// www.mindat.org/min-1420.html. Accessed 29 Apr 2016

5. Avalon Advanced Materials Inc. (2013) Nechalacho Resources \& Reserves. http://www.avalonadvancedmaterials.com/nechalacho/ resources_reserves/. Accessed 29 Apr 2016

6. Tasman Metals Ltd. (2015) Prefeasibility Study-NI 43-101Technical report for the Norra Kärr Rare Earth Element Deposit

7. Sjöqvist A, Cornell D, Andersen T et al (2014) Geochronology of the Norra Kärr alkaline complex, southern Sweden. In: 31st Nordic Geological Winter Meeting, Lund, 8-10 Jan 2014

8. Nayfonov T, Belborodov V, Zakharova I (1993) Flotation of complex titanium and zirconium ores. KSC RAS, Apatity (in Russian)

9. Zakharova I, Nayfonov T (1973) Flotation of eudialyte from ores. J Miner Process (Obogashchenie Rud) 5:23-25 (in Russian)

10. Ney P (1973) Zeta-Potentiale und Flotierbarkeit von Mineralen. Springer-Verlag, Wien/New York

11. Manser R (1975) Handbook of silicate flotation. Warren Spring Laboratory, Stevenage

12. Zakharova I, Nayfonov T (1974) A study on floatability of eudialyte and associated minerals. J Nonferr Metall (Tsvetnaya Metallurgiya) 1:12-16 (in Russian)

13. Nayfonov T, Belborodov V, Zakharova I et al (1991) Flotation technology for beneficiation of eudialyte ore. In: XVII international mineral processing congress, Dresden, 23-28 Sept 1991, vol IV, pp. 131-138

14. Bulatovic S (2013) Handbook of flotation reagents: chemistry, theory and practice: flotation of industrial minerals. Elsevier Science, Amsterdam

15. Bulatovic S, Salter R (1991) Flotation behaviour of some oxide and rare earth minerals during the treatment of complex oxidic ores. In: XVII International mineral processing congress, Dresden, 23-28 Sept 1991, vol IV, pp. 35-46

16. Polkin S (1987) Beneficiation of precious metals and rare mineral ores. Nedra, Moscow (in Russian)

17. Bjelopavlic M, Ralston J, Reynolds G (1998) Adsorption of monoalkyl phosphates at the zircon-aqueous solution interface. J Colloid Interface Sci 208(1):183-190. doi:10.1006/jcis.1998. 5778

18. Wotruba H (1991) Investigation of the flotation of microlite and zircon in special consideration of the influence of particle shape. Dissertation. RWTH Aachen, Aachen

19. Silin I (2015) Flotation of REE-bearing Zirconium silicates. Master Thesis. RWTH Aachen, Aachen

20. Clariant International AG (2013) Clariant mining solutions nonsulfide ores. http://www.clariant.in/C12575E4001FB2B8/vwLoo kupDownloads/Non-Sulfide\%20Ores.pdf/\$FILE/Non-Sulfide\%2 0Ores.pdf. Accessed 29 Apr 2016 